\title{
AVALIAÇÃO DA APTIDÃO AGRÍCOLA DAS TERRAS COMO SUBSÍDIO AO ASSENTAMENTO DE FAMÍLIAS RURAIS, UTILIZANDO SISTEMAS DE INFORMAÇÕES GEOGRÁFICAS ${ }^{(1)}$
}

\author{
Elisângela Benedet da Silva ${ }^{(2)}$, Ruth Emília Nogueira ${ }^{(3)}$ \& Antônio Ayrton \\ Auzani Uberti ${ }^{(4)}$
}

RESUMO

Os assentamentos rurais no Brasil foram criados para responder a pressões localizadas e estão marcados pela falta de planejamento prévio de implantação e diagnóstico dos recursos naturais relativos a aptidão agrícola, distribuição das classes de relevo, hidrografia, vegetação e mecanismos de apoio. O objetivo desta pesquisa foi avaliar a aptidão agrícola das terras destinadas ao assentamento de famílias rurais do Instituto Nacional de Colonização e Reforma Agrária (INCRA), aplicando o Sistema de Avaliação da Aptidão Agrícola das Terras (SAAT) associado a um Sistema de Informações Geográficas (SIG) no Projeto de Assentamento Eldorado dos Carajás (PAEC), localizado no município de Lebon Régis/SC. No desenvolvimento da pesquisa, optou-se por utilizar mapas temáticos em sistemas de informações geográficas (SIG) para armazenar e integrar os dados espaciais. $O$ uso do SIG permitiu a análise e integração dos temas com significativa redução de tempo e subjetividade nos cruzamentos. $\mathrm{O}$ uso do método forneceu duas respostas básicas ao planejamento de uso dos recursos naturais das áreas rurais: as classes de aptidão agrícola, apontando os principais fatores limitantes e a viabilidade de melhoramento das terras no nível tecnológico B; e, quando confrontado com os mapas temáticos e os dados cadastrais do assentamento, revelou as regularidades e irregularidades no uso das terras em cada parcela imobiliária.

Termos de indexação: avaliação de terras, planejamento agrícola, sustentabilidade e conservação de recursos naturais.

\footnotetext{
(1) Parte da Dissertação de Mestrado do primeiro autor apresentada ao Programa de Pós-Graduação em Engenharia Civil, Universidade Federal de Santa Catarina - UFSC. Recebido para publicação em setembro de 2009 e aprovado em maio de 2010 .

(2) Pesquisadora da Empresa de Pesquisa Agropecuária e Extensão Rural de Santa Catarina, Centro de Informações de Recursos Ambientais e de Hidrometeorologia de Santa Catarina - EPAGRI/CIRAM. Rod. Admar Gonzaga 1347, Itacorubi, CEP 88034901 Florianópolis (SC). E-mail: elis_benedet@yahoo.com.br

(3) Professora do Departamento de Geociências, Universidade Federal de Santa Catarina - UFSC. Campus Universitário, Trindade, CEP 88010-970 Florianópolis (SC). E-mail: ruthenogueira@gmail.com

(4) Professor aposentado do Departamento de Engenharia Rural, UFSC. E-mail: aaauberti@hotmail.com
} 


\title{
SUMMARY: LAND SUITABILITY EVALUATION AS SUBSIDY TO THE SETTLEMENT OF RURAL FAMYLIES, USING GEOGRAPHIC INFORMATION SYSTEM
}

\begin{abstract}
Rural settlements in Brazil were created in order to confront pressures and are characterized by the lack of planning prior to the diagnosis and implementation of the natural resources related to land suitability evaluation, distribution of classes such as topography, rivers system, vegetation, and support mechanisms. The aim of this study was to evaluate the agricultural capacity of the lands which were allotted to the settlement of rural families by the National Institute of Colonization and Land Reform (INCRA), applying the system of Agricultural Evaluation and Land Suitability (SAAT) associated with a Geographical Information System (GIS) functioning at the Eldorado dos Carajás Settlement Project, located in the municipality of Lebon Régis, SC, Brazil. In order to carry out the study there was a choice to use thematic maps from geographical information systems so that the special data could be stored and integrated. The use of the SIG made possible the analysis and integration of the themes with significant time reduction and subjectivity in the crossings of data. The use of this methodology provided two threshold responses to the planning of the use of rural areas natural resources: the classes of agricultural capacity, highlighting the main limiting factors and the viability of land improvement on technological B level of the methodology; and when confronting the thematic maps and the recorded data of the settlement, both regularities and irregularities in the use of the land in each area were revealed.
\end{abstract}

Index terms: land evaluation, agricultural planning, sustainability and conservation of natural resources.

\section{INTRODUÇÃO}

Os assentamentos rurais no Brasil passaram a existir oficialmente a partir da década de 1980 e foram criados para responder às pressões localizadas, como forma de mitigar conflitos relacionados à posse da terra. Marcados pela falta de um planejamento prévio de implantação e de mecanismos de apoio, muitos desses assentamentos enfrentam situações bastante adversas no que se refere à estabilidade das parcelas, com evidentes reflexos sobre as condições de produção e comercialização, formas de organização e preservação dos recursos naturais.

A problemática da ocupação da terra em assentamentos rurais e as precárias condições da agricultura familiar nessas áreas têm sido tema de diversas pesquisas, como as de Wolstein et al. (1998), Ramos et al. (2001), Cardoso et al. (2002) e Silva (2006), que propõem novos métodos de planejamento, implantação e manutenção de assentamentos rurais. Essas pesquisas apontam as diversidades ambientais e socioeconômicas dessas áreas, chamando a atenção dos órgãos competentes para uma revisão dos conceitos e técnicas utilizados até o momento para avaliação de terras visando à desapropriação e ao assentamento de famílias pelo INCRA.

Inúmeros são os trabalhos que empregam o Sistema de Avaliação da Aptidão Agrícola das Terras (SAAT), elaborado por Ramalho Filho \& Beek (1995) para avaliação de terras no Brasil, nos mais variados níveis de detalhe e adaptações. Citam-se, entre outros, Hamada et al. (2006), Vasconcelos Gomes et al. (2005) e Calderano Filho et al. (2004).
Muitos desses estudos têm sido realizados utilizando-se sistemas de informações geográficas (SIG), entre os quais destacam-se, com resultados bastante promissores na avaliação da aptidão agrícola das terras, os trabalhos de Formaggio et al. (1992), Lopes Assad et al. (1998), Fernandes et al. (1998) e Pedron et al. (2006); e na avaliação de terras por meio de sistemas especialistas, segundo método da FAO, os de Bacic (1998) e Chagas et al. (2006).

Nesse contexto, o presente trabalho propôs o uso do Sistema de Avaliação da Aptidão Agrícola das Terras (SAAT) elaborado por Ramalho Filho \& Beek (1995) para avaliação da aptidão agrícola das terras destinadas aos assentamentos rurais, tomando como caso de estudo o Projeto de Assentamento Eldorado dos Carajás (PAEC). Associada à avaliação da aptidão agrícola das terras, foi realizada uma análise dos conflitos decorrentes de adequações e inadequações de uso das terras nas parcelas imobiliárias.

\section{MATERIAL E MÉTODOS}

O Projeto de Assentamento Eldorado dos Carajás - PAEC (Figura 1) está localizado no município de Lebon Régis/SC, entre os paralelos $26^{\circ} 30^{\prime} 0$ " e $27^{\circ} 50$ ' 0 " de Latitude Sul e meridianos $50^{\circ} 55^{\prime} 0$ " e $50^{\circ} 30$ ' 0 " de Longitude Oeste, a 21,5 km da sede do município.

Ocupa uma área territorial de 216 ha, parcelada em 21 lotes, constituídos por 19 unidades agrícolas familiares com área média de 9,0 ha, que varia de 7,4 a 11,4 ha, uma área comunitária de 1,45 e 42,10 ha averbados como área de reserva legal. 


\section{MAPA DE LOCALIZAÇÃO DA ÁREA DE ESTUDO}

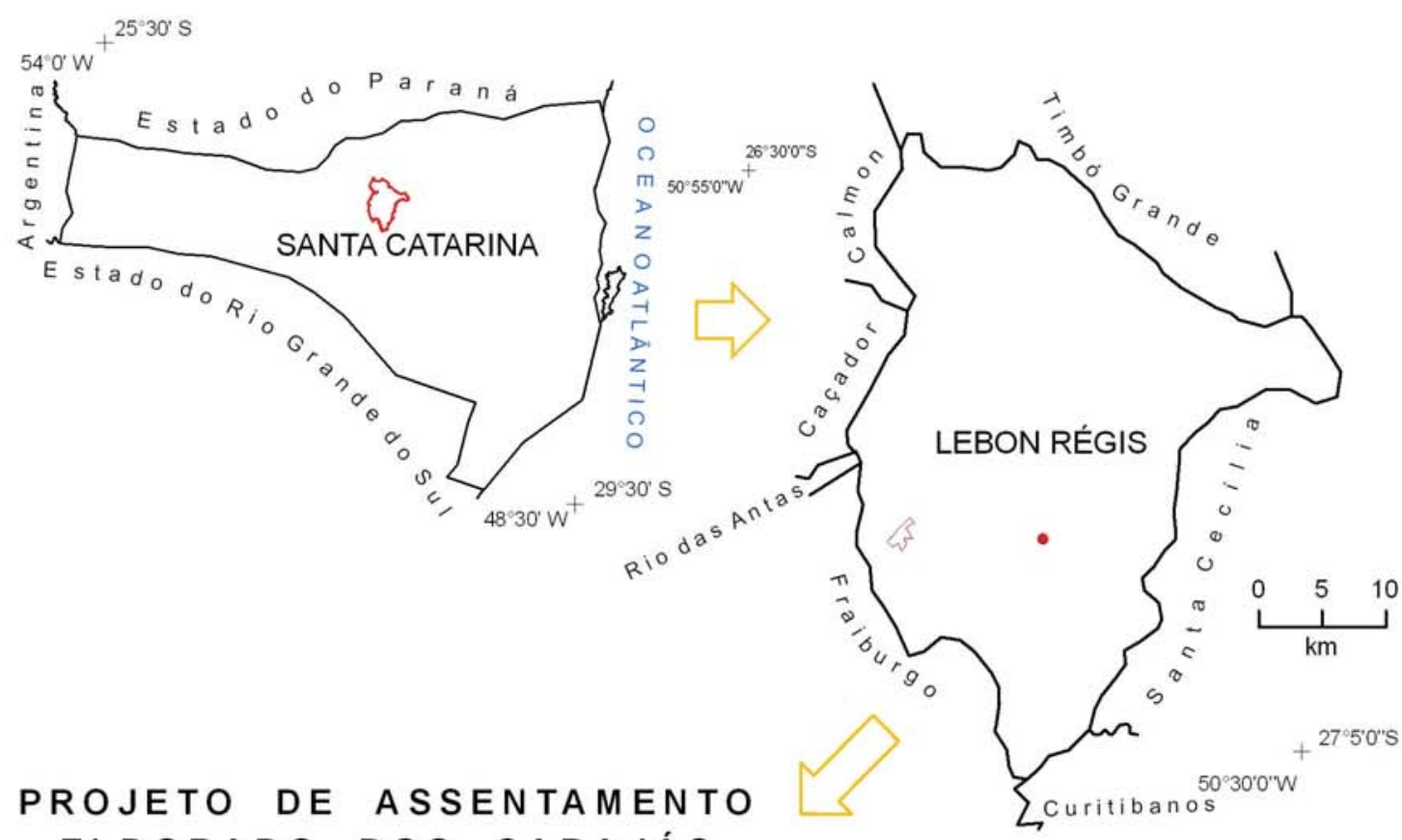

ELDORADO DOS CARAJÁS

\section{LEGENDA}

1 - 21Parcelas Imobiliárias

Limite das parcelas imobiliárias

- Sangas

E Estrada municipal

Estrada vicinal

Limite do imóvel
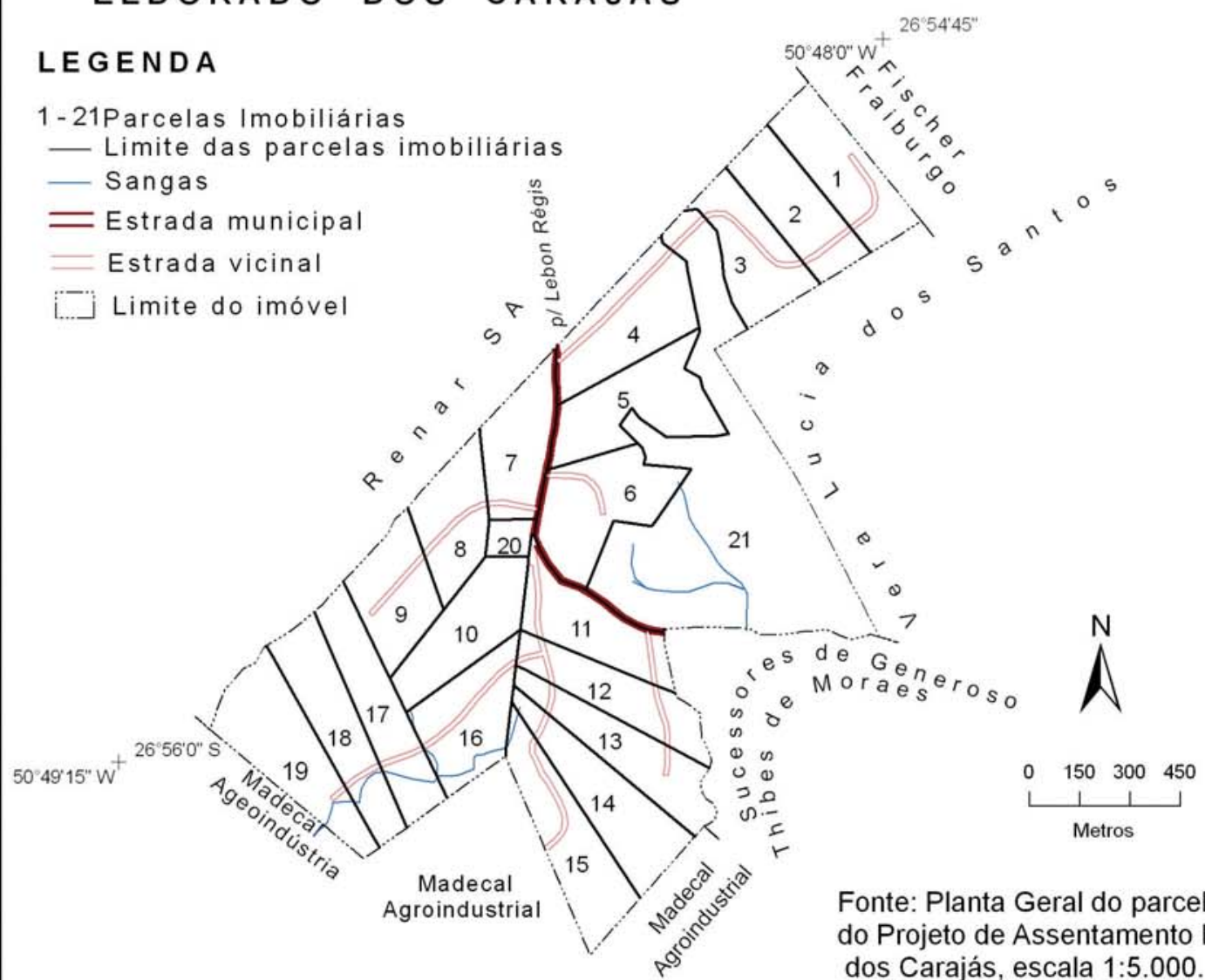

Fonte: Planta Geral do parcelamento do Projeto de Assentamento Eldorado dos Carajás, escala 1:5.000. (INCRA)

Figura 1. Mapa de localização da área de estudo. 
Os produtos cartográficos digitais utilizados na realização da pesquisa foram cedidos pelo INCRA/SC na extensão *.dwg, sendo eles: (a) levantamento planialtimétrico na escala 1:5.000; (b) planta geral do parcelamento na escala 1:5.000; (c) mapa de uso atual do solo (2006) do assentamento em escala 1:10.000; e (d) hidrografia na escala 1:15.000. O mapa de solos e o mapa de declividade do PAEC foram elaborados em escala 1:16.000 por Silva (2007).

Para o cruzamento dos dados alfanuméricos e cartográficos e edição dos arquivos vetoriais e dos mapas finais, utilizou-se o programa computacional do tipo Sistema de Informação Geográfica (SIG), $\operatorname{ArcGis}^{\circledR}$ versão 9.1. Para atualização das informações no campo foi usado um aparelho receptor de sinais de satélites artificiais do sistema GPS (Global Positioning System), modelo Etrex ${ }^{\circledR}$ (Garmin).

Conforme mencionado, a avaliação da aptidão agrícola das terras da área de estudo foi efetuada com base no Sistema de Avaliação da Aptidão Agrícola das Terras (SAAT) proposto por Ramalho Filho \& Beek (1995). O SAAT admite seis grupos e quatro classes de aptidão agrícola em três níveis tecnológicos. Os grupos de aptidão 1, 2 e 3 identificam terras cujo uso mais intensivo é a lavoura. O grupo 4 representa terras cujo tipo de uso mais intensivo é a pastagem plantada, enquanto no grupo 5 o uso mais intensivo das terras limita-se à silvicultura e pastagem natural. O grupo 6 abrange áreas de terras consideradas inaptas para qualquer uma das atividades agrícolas citadas, estando sua ocupação condicionada à preservação da fauna e da flora.

As classes de aptidão (boa, regular, restrita e inapta) são definidas para um determinado tipo de uso em função dos graus de limitação (N: nulo, L: ligeiro, M: moderado, F: forte e MF: muito forte) em cada gleba de terra.

No método, os níveis tecnológicos revelam o conjunto de tecnologias empregadas pelo agricultor e evoluem do nível A para o C (A-baixo, B-médio e Calto). Quanto mais elevado o nível tecnológico (nível C), maior a inversão de capital e tecnologias, aumentando as possibilidades de superar as condições limitantes de uma determinada gleba de terra e viabilizar produções economicamente sustentadas. As terras do PAEC foram classificadas considerando o nível tecnológico médio empregado no assentamento, definido no método como nível de manejo B.

O mapa de solos $\left(\mathrm{PI}_{1}\right)$, o mapa de classes de declividade $\left(\mathrm{PI}_{2}\right)$ e os fatores limitantes $\left(\mathrm{PI}_{3 \mathrm{a}}\right)$, elaborados por Silva (2007), constituíram planos de informação (PI) distintos, que serviram de dados de entrada no SIG.

O mapa de solos foi elaborado em nível de semidetalhe a partir do levantamento de solos de Santa Catarina (Embrapa, 1998) por restituição fotogramétrica digital, checagem de campo e análise de laboratório e apresentado na escala 1:16 000. Os solos foram classificados segundo Embrapa (2006) em três unidades de mapeamento distintas, descritas a seguir.

A unidade de mapeamento mais representativa é caracterizada pelo Nitossolo Vermelho distroférrico típico - NVdf e recobre 165 ha $(76,5 \%)$ da área do assentamento. São solos de horizonte A proeminente, com espessura de $35 \mathrm{~cm}$ sobre um horizonte B nítico. Apresenta saturação por alumínio acima de $65 \%$. Com 4,90 dag kg-1 de matéria orgânica (MO), valor considerado médio, estes solos requerem elevadas doses de corretivo, uma vez que apresentam elevada acidez potencial $\left(24,41 \mathrm{cmol}_{\mathrm{c}} \mathrm{dm}^{-3}\right)$. Do ponto de vista físico, são solos bem drenados, com espessura do solum (A+B) variando entre 1,5 e $2,5 \mathrm{~m}$ ou mais, com acentuado desenvolvimento de estrutura e cerosidade. Esses solos predominam nas áreas mais extensas, de relevo ondulado e forte ondulado.

A segunda unidade é representada pelo Neossolo Litólico distroférrico - RLd, que cobre 27 ha, equivalente a 12,5\% da área. Esses solos apresentam horizonte A proeminente, bem drenados, com espessura de $35 \mathrm{~cm}$ sobre rocha fragmentada. Dos solos mapeados na área, o Neossolo Litólico apresentou 4,10 dag kg-1 de MO, o menor valor de $\mathrm{Al}^{3+}$ trocável $\left(2,90 \mathrm{cmol}_{\mathrm{c}} \mathrm{dm}^{-3}\right)$ e o menor valor de acidez potencial $\left(19,40 \mathrm{cmol}_{\mathrm{c}} \mathrm{dm}^{-3}\right)$. Esses solos predominam na classe de relevo forte ondulado, mas a presença de pedras na massa do solo e afloramentos de rocha ocorre em todas as classes de relevo.

A unidade menos representativa é formada por Gleissolo Melânico Alumínico típico - GMa, abrangendo 24,5 ha, 11 \% da área do imóvel. São solos minerais, hidromórficos, pouco desenvolvidos, de horizonte superficial A húmico com $60 \mathrm{~cm}$ de espessura seguido de horizonte subsuperficial glei. Embora a saturação por alumínio no horizonte A seja de $40 \%$, esses solos apresentam valores muito altos de $\mathrm{Al}$ trocável $\left(3,5 \mathrm{cmol}_{\mathrm{c}} \mathrm{dm}^{-3}\right)$, altos teores de MO $\left(6,3 \mathrm{dag} \mathrm{kg}^{-1}\right)$ e elevada acidez potencial $\left(21,76 \mathrm{cmol}_{\mathrm{c}} \mathrm{dm}^{-3}\right)$. O afloramento do lençol freático a $60 \mathrm{~cm}$ da superfície ocorre durante a maior parte do ano, caracterizando solos mal drenados e com permeabilidade muito baixa. São solos desenvolvidos nas áreas mais deprimidas da paisagem, predominando na classe de relevo plano de 0 a $3 \%$.

Para interpretação do relevo, foi elaborado o mapa de declividade a partir do Modelo Digital do Terreno MDT. Das seis classes de relevo propostas, segundo Embrapa (2006), apenas cinco foram identificadas na área: 0 a $3 \%$ (plano), 3,1 a $8 \%$ (suave ondulado), 8,1 a $20 \%$ (ondulado), 20,1 a $45 \%$ (forte ondulado) e 45,1 a $75 \%$ (montanhoso). As classes mais expressivas são a ondulada (8 a $20 \%$ ), ocupando $47 \%$ da área, e a forte ondulada (20 a $45 \%$ ), com 29 \% da área de estudo.

O plano de informação cadastro $\left(\mathrm{PI}_{8}\right)$ foi elaborado a partir do levantamento planialtimétrico realizado pelo INCRA. Nele estão contidos os elementos que 
compõem a estrutura fundiária do assentamento, como o limite territorial do PAEC, a identificação dos confrontantes, a distribuição e identificação das 21 parcelas imobiliárias, as estradas municipais e vicinais, a localização geográfica do assentamento e a hidrografia. Essas feições compuseram a base cartográfica dos mapas temáticos compilados na escala de 1:16 000 .

A avaliação da aptidão agrícola das terras foi determinada por meio de estudo comparativo entre os graus de limitação atribuídos aos fatores limitantes das unidades de mapeamento de solos do assentamento e os preestabelecidos no quadro-guia para região subtropical, proposto por Ramalho Filho \& Beek (1995). Os graus de limitação foram atribuídos às terras em condições naturais e também após a simulação de práticas de melhoramento do SAAT compatíveis com o nível de manejo $\mathrm{B}$ para os $\mathrm{PI}_{3}$ ao $\mathrm{PI}_{7}$

O cruzamento dos sete planos de informação resultou em um quadro (Quadro 1) com todas as combinações possíveis de informações. As combinações foram geradas, no SIG, pela concatenação dos códigos na tabela de atributos do $\mathrm{PI}_{1}$. Esse processo criou um identificador de classe único para cada combinação possível dos tipos de informação utilizada. Esse identificador foi convertido da representação numérica para a alfabética, conforme o método, e recodificado, criando-se um novo código com a classe de aptidão agrícola para cada polígono de solo da área de estudo.

Para classificação do uso e cobertura das terras foi utilizado o mapa de Uso Atual do Solo (2006), em escala 1:10.000, cedido pelo INCRA/SC, modificado e atualizado em campo pelo primeiro autor em maio de 2007. A partir da reclassificação e atualização, foi elaborado um novo mapa, denominado de Mapa de Uso e Cobertura das Terras, com as seguintes classes: Açudes, Banhados, Cultivos Agrícolas, Solo Exposto e, ou, Arado, Vegetação em Estádio Inicial de Regeneração Natural e, ou, Pastagem, Vegetação em
Estádio Médio de Regeneração Florestal e Vegetação em Estádio Avançado de Regeneração Florestal.

Para elaboração do mapa de Áreas de Interesse Ambiental, as áreas foram definidas com base na Lei $n^{\circ} 4771 / 65$, que institui o Código Florestal (Brasil, 1965), e na Resolução CONAMA n ${ }^{0}$ 303/2002, que dispõe sobre os parâmetros, definições e limites de Áreas de Preservação Permanente (CONAMA, 2002).

As áreas de preservação permanente de banhado foram classificadas no SIG, criando-se um buffer de largura igual a $50 \mathrm{~m}$ nas classes banhados e açudes do mapa de Uso e Cobertura das Terras. Nas áreas de preservação permanente ao longo dos rios foi criado um buffer de largura igual a $30 \mathrm{~m}$ no mapa da Hidrografia, uma vez que todos os rios da área apresentam largura inferior a $10 \mathrm{~m}$ (Incra, 2006). Para representação da área de reserva legal, foi importado para o SIG o plano de informação referente à área de reserva legal da planta geral de parcelamento do PAEC.

O mapa de Conflitos de Uso das Terras foi elaborado, no SIG, a partir da sobreposição dos mapas de Aptidão Agrícola, Uso e Cobertura das Terras e Áreas de Interesse Ambiental. Foi possível avaliar, por parcela imobiliária, cada classe de aptidão agrícola segundo o uso e cobertura da terra e interesse ambiental. O processo de avaliação foi elaborado por reclassificação, em que cada classe de aptidão agrícola foi isolada em um plano de informação específico. As classes de conflito de uso seguiram uma classificação adaptada de Santos \& Klamt (2004): (a) Uso Satisfatório/Adequado - áreas em que o uso atual atende à classe de aptidão agrícola definida; (b) Subutilizado - compreende as áreas em que o uso é menos intensivo do que o recomendado pela classe de aptidão agrícola; (c) Sobreutilizado/Inadequado compreende áreas em que o uso atual é mais intensivo que o recomendado pela classe de aptidão agrícola; e (d) Conflito Ambiental - compreende áreas em que o uso fere as leis ambientais aplicadas.

\section{Quadro 1. Concatenação dos códigos dos temas integrados}

\begin{tabular}{|c|c|c|c|c|c|c|c|c|c|}
\hline \multirow{2}{*}{$\mathbf{P I}_{1}$} & \multirow{2}{*}{$\mathrm{PI}_{2}$} & \multicolumn{5}{|c|}{ Fatores limitantes } & \multirow{2}{*}{$\begin{array}{l}\text { Identificador } \\
\text { de classe }\end{array}$} & \multirow{2}{*}{ Grau de limitação } & \multirow{2}{*}{ Classe de aptidão agrícola } \\
\hline & & $\mathrm{PI}_{3}$ & $\mathrm{PI}_{4}$ & $\mathrm{PI}_{5}$ & $\mathrm{PI}_{6}$ & $\mathrm{PI}_{7}$ & & & \\
\hline RLd & 4 & 2 & 0 & 0 & 3 & 3 & 20033 & MNNFF & 4p-regular para pastagem \\
\hline RLd & 5 & 2 & 0 & 0 & 4 & 4 & 20044 & MNN MF MF & Sem aptidão agrícola \\
\hline RLd & 2 & 2 & 0 & 0 & 1 & 2 & 20012 & MNNLM & 3 (b)-restrita para lavoura \\
\hline RLd & 3 & 2 & 0 & 0 & 2 & 2 & 20022 & MNNMM & 3(b)-restrita para lavoura \\
\hline GMd & 1 & 2 & 0 & 3 & 0 & 4 & 20304 & MNFN MF & Sem aptidão agrícola \\
\hline GMd & 2 & 2 & 0 & 3 & 1 & 4 & 20314 & MNFL MF & Sem aptidão agrícola \\
\hline NVdf & 3 & 2 & 0 & 0 & 2 & 2 & 20022 & MNNMM & 3 (b)-restrita para lavoura \\
\hline NVdf & 5 & 2 & 0 & 0 & 4 & 4 & 20044 & MNN MF MF & Sem aptidão agrícola \\
\hline NVdf & 2 & 2 & 0 & 0 & 1 & 1 & 20011 & MNNLL & 3 (b)-restrita para lavoura \\
\hline NVdf & 1 & 2 & 0 & 0 & 0 & 0 & 20000 & MNNNN & 3(b)-restrita para lavoura \\
\hline NVdf & 4 & 2 & 0 & 0 & 3 & 3 & 20033 & MNNFF & 4p-regular para pastagem \\
\hline
\end{tabular}

$\mathrm{PI}_{1}$ - Unidades de mapeamento: RLd-Neossolo Litólico distrófico; GMa-Gleissolo Melânico alumínico; NVdf- Nitossolo Vermelho distroférrico; $\mathrm{PI}_{2}$-classes de declividade: 1(0-3 \%); 2(3,1-8 \%); 3(8,1-20\%); 4(20,1-45 \%); 5(45,1-75 \%); Graus de limitação: 0(nulo0); 1(ligeiro); 2(moderado); 3(forte); 4(muito forte). 


\section{RESULTADOS E DISCUSSÃO}

\section{Uso e cobertura das terras}

Quanto ao uso das terras, os valores percentuais revelam que cerca de $27 \%$ das terras são utilizadas com a classe Cultivos Agrícolas, em amarelo na figura 2, e 9 \% com a classe Solo exposto e, ou, Arado, em laranja na figura 2 , ou seja, aproximadamente $37 \%$ das terras do assentamento são utilizadas para atividades agrícolas de uso mais intensivo (Quadro 2).

Das atividades agrícolas de uso mais intensivo do solo, no caso, os cultivos agrícolas produzidos e comercializados no assentamento limitam-se predominantemente à produção de milho e feijão. Essas atividades predominam nos lotes 4, 7, 8, 9, 10, 11, 12, 13, 14, 17, 18 e 20 (Quadro 3).

$\mathrm{O}$ sistema de autoconsumo descrito por Guanziroli et al. (2001) é reproduzido no PAEC pela associação dos fatores limitantes das terras com a limitada inversão de capital dos agricultores recém-assentados. Os fatores limitantes correspondem à baixa fertilidade natural das três classes de solos que cobrem o assentamento, associada às limitações físicas impostas pelo relevo acidentado que determinou a formação de solos rasos e pedregosos, como os RLd, característicos da porção sudoeste do assentamento, ou situações de relevo plano que contribuíram para a formação de solos mal drenados com permeabilidade muito baixa, como os GMa.
A classe Vegetação em Estádio Inicial de Regeneração e, ou, Pastagem, conforme apresentado no quadro 2 , abrange cerca de $26 \%$ das terras do assentamento e apresenta dois tipos de ocupação: vegetação em estádio inicial de regeneração florestal e áreas com pastagens. Esta classe predomina, como destacado em negrito no quadro 4, nos lotes 3, 5, 6, 15 e 16 .

Nos trabalhos em campo, verificou-se que em alguns lotes, além das duas classes representadas no mapa (Figura 2), há uma terceira classe, formada por áreas agrícolas em pousio. Estas áreas não aparecem individualizadas em função da escala de mapeamento e da data de captura da imagem pelo sensor. Dependendo do período de pousio, que pode ocorrer durante alguns anos, pode-se facilmente confundi-lo com a classe Vegetação em Estádio Inicial e, ou, Pastagem na interpretação visual das imagens. Nesse caso, se for considerado o pousio, o quantitativo de áreas utilizadas com a classe Cultivos Agrícolas na área de estudo ultrapassa os $27 \%$ espacializados no mapa (Figura 2).

A classe Vegetação em Estádio Médio de Regeneração Florestal abrange aproximadamente $22 \%$ da área do assentamento (Quadro 2), com predomínio nos lotes 1, 2, 19 e 21, destacados em negrito no quadro 5 . A reserva legal do assentamento (lote 21, Figura 2) encerra cerca de $36 \%$ desta classe. A madeira é o principal produto explorado, com destaque para a bracatinga.

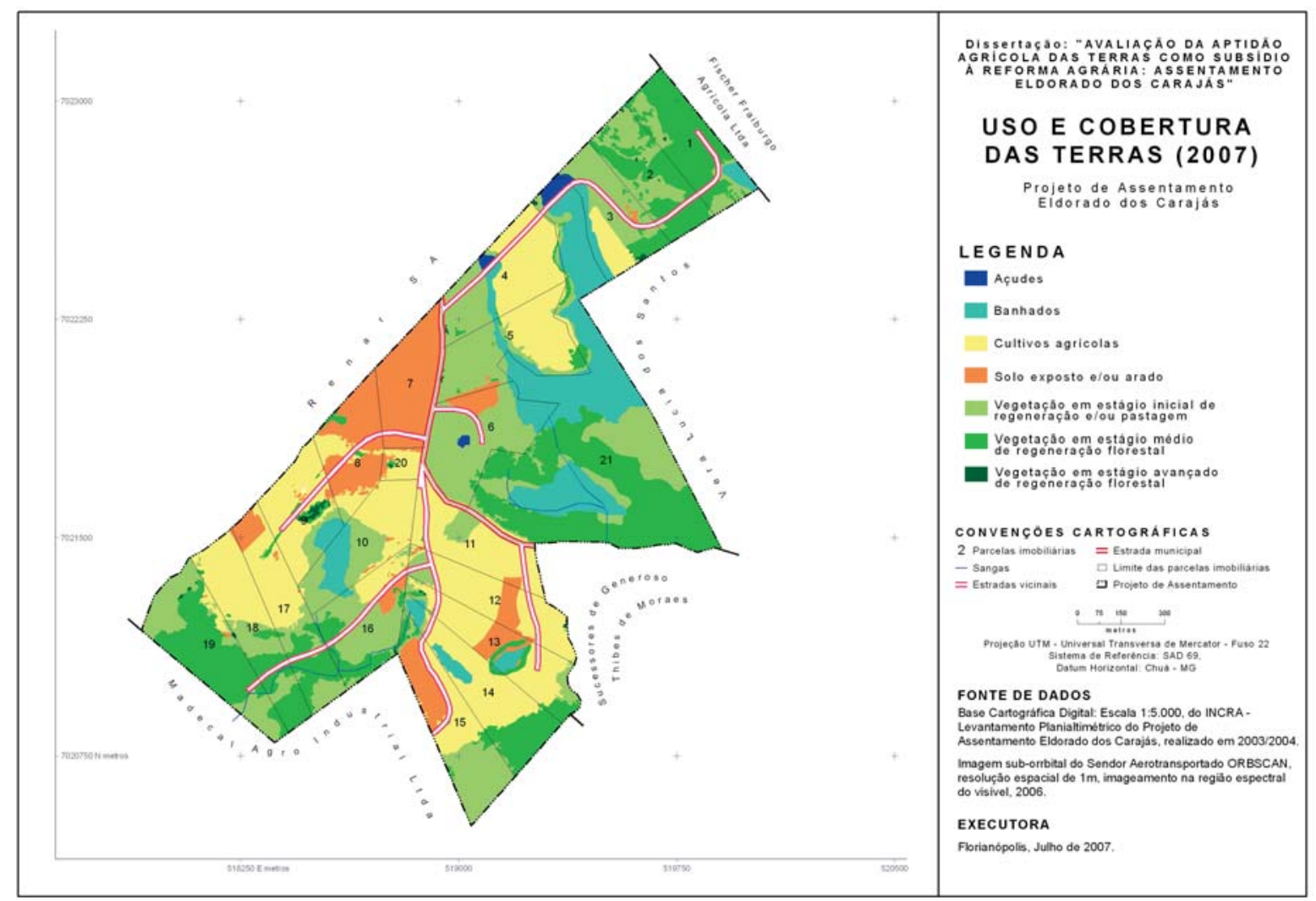

Figura 2. Mapa de uso e cobertura das terras do PAEC. 
Quadro 2. Distribuição absoluta (ha) e relativa (\%) das classes de uso e cobertura das terras no Projeto de Assentamento Eldorado dos Carajás

\begin{tabular}{|c|c|c|c|c|c|c|c|c|c|}
\hline \multirow{3}{*}{$\begin{array}{c}\text { Parcelas } \\
\text { imobiliárias }\end{array}$} & \multirow{3}{*}{ Área } & \multirow{3}{*}{ Estradas } & \multicolumn{6}{|c|}{ Uso e cobertura das terras -2007} & \\
\hline & & & \multirow[t]{2}{*}{ Açudes } & \multirow[t]{2}{*}{ Banhados } & \multirow{2}{*}{$\begin{array}{l}\text { Cultivos } \\
\text { agrícolas }\end{array}$} & \multirow{2}{*}{$\begin{array}{c}\text { Solo } \\
\text { exposto }\end{array}$} & \multicolumn{3}{|c|}{ Vegetação } \\
\hline & & & & & & & $\begin{array}{c}\text { Inicial e, ou, } \\
\text { pastagem }\end{array}$ & $\begin{array}{l}\text { Estádio } \\
\text { médio }\end{array}$ & $\begin{array}{c}\text { Estádio } \\
\text { avançado }\end{array}$ \\
\hline & $\longrightarrow$ & ha- & & & & - ha $(\%)$ & 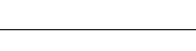 & & - \\
\hline Total & 216,0 & 8,4 & $\begin{array}{l}0,92 \\
(0,4 \%)\end{array}$ & $\begin{array}{l}23,68 \\
(11 \%)\end{array}$ & $\begin{array}{l}58,68 \\
(27,2 \%)\end{array}$ & $\begin{array}{l}20,42 \\
(9,4 \%)\end{array}$ & $\begin{array}{l}55,35 \\
(25,6 \%)\end{array}$ & $\begin{array}{c}48,29 \\
(22,3 \%)\end{array}$ & $\begin{array}{l}0,26 \\
(0,1 \%)\end{array}$ \\
\hline
\end{tabular}

Quadro 3. Distribuição absoluta e relativa das classes de uso e cobertura das terras por lote

\begin{tabular}{|c|c|c|c|c|c|c|c|c|c|}
\hline \multirow{3}{*}{$\begin{array}{c}\text { Parcelas } \\
\text { imobiliárias }\end{array}$} & \multirow{3}{*}{ Área } & \multirow{3}{*}{ Estradas } & \multicolumn{6}{|c|}{ Uso e cobertura das terras -2007} & \\
\hline & & & \multirow[t]{2}{*}{ Açudes } & \multirow[t]{2}{*}{ Banhados } & \multirow{2}{*}{$\begin{array}{l}\text { Cultivos } \\
\text { agrícolas }\end{array}$} & \multirow{2}{*}{$\begin{array}{c}\text { Solo } \\
\text { exposto }\end{array}$} & \multicolumn{3}{|c|}{ Vegetação } \\
\hline & & & & & & & $\begin{array}{l}\text { Inicial e, ou, } \\
\text { pastagem }\end{array}$ & $\begin{array}{l}\text { Estádio } \\
\text { médio }\end{array}$ & $\begin{array}{c}\text { Estádio } \\
\text { avançado }\end{array}$ \\
\hline & & ha- & & & & - ha (\%) & & & 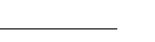 \\
\hline Lote 4 & 10,4 & 0,8 & 0,2 & 0,55 & $5,7(55 \%)$ & - & 2,95 & 0,2 & - \\
\hline Lote 7 & 7,8 & 0,6 & - & - & - & $7,2(92 \%)$ & - & - & - \\
\hline Lote 8 & 7,4 & 0,4 & - & . & 1,6 & $5,0(68 \%)$ & 0,15 & 0,25 & - \\
\hline Lote 9 & 7,8 & 0,4 & - & 0,7 & $5,24(67 \%)$ & 0,1 & 0,8 & 0,3 & 0,26 \\
\hline Lote 10 & 8,8 & - & - & 1,64 & $3,85(44 \%)$ & 0,13 & 3,18 & - & - \\
\hline Lote 11 & 8,3 & 1,1 & - & - & $6,17(74 \%)$ & 0,18 & 0,85 & - & - \\
\hline Lote 12 & 8,0 & 0,6 & - & - & $5,7(71 \%)$ & 1,1 & 0,6 & - & - \\
\hline Lote 13 & 8,6 & 0,3 & - & 0,55 & $4,6(53 \%)$ & 1,2 & 0,87 & 1,08 & - \\
\hline Lote 14 & 9,8 & 0,1 & - & 1,1 & $5,3(54 \%)$ & & 0,3 & 3,0 & - \\
\hline Lote 17 & 9,3 & 0,2 & - & - & $3,9(42 \%)$ & 0,98 & 1,85 & 2,37 & - \\
\hline Lote 18 & 9,4 & 0,2 & - & - & $4,6(49 \%)$ & & 2,0 & 2,6 & - \\
\hline Lote 20 & 1,4 & - & - & - & $1,1(79 \%)$ & 0,3 & - & - & - \\
\hline
\end{tabular}

Quadro 4. Distribuição absoluta e relativa das classes de uso e cobertura das terras por lote

\begin{tabular}{|c|c|c|c|c|c|c|c|c|c|}
\hline \multirow{3}{*}{$\begin{array}{c}\text { Parcelas } \\
\text { imobiliárias }\end{array}$} & \multirow{3}{*}{ Área } & \multirow{3}{*}{ Estradas } & \multicolumn{6}{|c|}{ Uso e cobertura das terras - 2007} & \\
\hline & & & \multirow[t]{2}{*}{ Açudes } & \multirow[t]{2}{*}{ Banhados } & \multirow{2}{*}{$\begin{array}{l}\text { Culturas } \\
\text { agricolas }\end{array}$} & \multirow{2}{*}{$\begin{array}{c}\text { Solo } \\
\text { exposto }\end{array}$} & \multicolumn{3}{|c|}{ Vegetação } \\
\hline & & & & & & & $\begin{array}{c}\text { Inicial e, ou, } \\
\text { pastagem }\end{array}$ & $\begin{array}{l}\text { Estádio } \\
\text { médio }\end{array}$ & $\begin{array}{c}\text { Estádio } \\
\text { avançado }\end{array}$ \\
\hline & 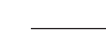 & ha & & & & ha $(\%)$ & & & \\
\hline Lote 3 & 8,2 & 0,5 & 0,1 & 1,0 & 1,65 & 0,15 & $4,0(49 \%)$ & 0,8 & - \\
\hline Lote 5 & 10,3 & 0,1 & - & 0,8 & 4,4 & 0,25 & $4,5(44 \%)$ & 0,25 & - \\
\hline Lote 6 & 10,6 & 0,7 & 0,12 & 1,15 & - & 0,95 & $7,5(71 \%)$ & 0,18 & - \\
\hline Lote 15 & 10,2 & 0,6 & - & - & 2,6 & 2,3 & $4,2(41 \%)$ & 0,5 & - \\
\hline Lote 16 & 8,9 & 0,6 & - & 0,1 & 1,36 & 0,58 & $4,4(49 \%)$ & 1,86 & - \\
\hline
\end{tabular}

A classe Vegetação em Estádio Avançado de Regeneração Florestal, formada por fragmentos florestais pouco representativos para caracterizar a formação vegetal original de Floresta Ombrófila Mista Montana característica do planalto catarinense, ocorre em $0,1 \%$ da área, mas a generalização da escala de mapeamento permitiu a sua representação apenas no lote 9 (Figura 2).
A classe Açudes cobre menos de $1 \%$ da área total do assentamento (Quadro 2). Os açudes em azul no mapa da figura 2 ocorrem nos lotes $3,4,6$ e 21 e constituem áreas de banhado represadas pelos agricultores para fornecimento de água aos animais. No lote 3 , além de garantir o acesso dos animais à água, o açude é explorado com a criação de peixes em consórcio com alguns suínos. 
A classe Banhados abrange $11 \%$ da área do assentamento - cerca de 24 ha (Quadro 1). Esses 24 ha de banhados estão distribuídos nos lotes $1,3,4$, 5, 6, 9, 10, 13, 14, 16 e 21 (Figura 2). Os agricultores desses lotes revelaram, em conversa pessoal, interesse em transformar as áreas de banhado em açudes para criação de peixes. No lote 21 , averbado como área de reserva legal, o banhado cobre aproximadamente $65 \%$ da área (Figura 2).

As Áreas de Interesse Ambiental (AIA) são apresentadas no quadro 6 e mostradas no mapa de Areas de Interesse Ambiental (Figura 3).

Dos 216 ha de terras do assentamento, aproximadamente $45,3 \mathrm{ha}(21 \%)$ representam a classe Faixa de domínio hídrico formada pela faixa marginal dos banhados e rios e 24,5 ha (11\%) enquadram-se na classe Banhados, como mostra o quadro 6. Essas áreas representam $32 \%$ da área total do assentamento e são consideradas pela Resolução CONAMA 303/02 como áreas de preservação permanente.

A área média dos lotes corresponde a aproximadamente 9 ha por família, variando do menor, com 7,4 ha (lote 8 , quadro 6, figura 3), ao maior, com 11,4 ha (lote 19 , quadro 6 , figura 3). A adequação de uso dos $32 \%$ de áreas de preservação permanente geraria uma retração na área média útil dos lotes de 9 ha para 5,5 ha. Essa redução é significativa nos lotes: 3 (com $41 \%$ de redução da área útil), 4 (com $44 \%), 5$ (com $44 \%$ ), 6 (com $39 \%$ ), 10 (com $44 \%$ ), 13 (com $34 \%$ ), 14 (com $43 \%$ ) e 16 (com $40 \%$ ), destacados em negrito no quadro 6.

Quadro 5. Distribuição absoluta e relativa das classes de uso e cobertura das terras por lote

\begin{tabular}{|c|c|c|c|c|c|c|c|c|c|}
\hline \multirow{3}{*}{$\begin{array}{c}\text { Parcelas } \\
\text { imobiliárias }\end{array}$} & \multirow{3}{*}{ Área } & \multirow{3}{*}{ Estradas } & \multicolumn{6}{|c|}{ Uso e cobertura das terras - 2007} & \\
\hline & & & \multirow[t]{2}{*}{ Açudes } & \multirow[t]{2}{*}{ Banhados } & \multirow{2}{*}{$\begin{array}{l}\text { Culturas } \\
\text { agrícolas }\end{array}$} & \multirow{2}{*}{$\begin{array}{c}\text { Solo } \\
\text { exposto }\end{array}$} & \multicolumn{3}{|c|}{ Vegetação } \\
\hline & & & & & & & $\begin{array}{c}\text { Inicial e, ou, } \\
\text { pastagem }\end{array}$ & $\begin{array}{l}\text { Estádio } \\
\text { médio }\end{array}$ & $\begin{array}{c}\text { Estádio } \\
\text { avançado }\end{array}$ \\
\hline & 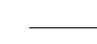 & $\mathrm{ha}-$ & 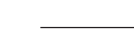 & 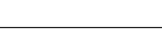 & 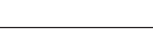 & — ha (\%) & & & 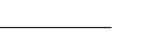 \\
\hline Lote 1 & 9,0 & 0,4 & - & 0,65 & - & - & 1,75 & $6,2(69 \%)$ & - \\
\hline Lote 2 & 8,3 & 0,3 & - & - & - & - & 3,3 & $4,7(57 \%)$ & - \\
\hline Lote 19 & 11,4 & 0,1 & - & - & 0,45 & - & 4,15 & $6,7(59 \%)$ & - \\
\hline Lote 21 & 42,1 & 0,4 & 0,5 & 15,44 & 0,46 & - & 8,0 & $17,3(41 \%)$ & - \\
\hline
\end{tabular}

Quadro 6. Distribuição absoluta e relativa das áreas de interesse ambiental por lote

\begin{tabular}{|c|c|c|c|}
\hline \multirow{2}{*}{ Parcelas Imobiliárias } & \multirow{2}{*}{ Área } & \multicolumn{2}{|c|}{ Áreas de interesse ambiental } \\
\hline & & APP banhados & APP faixa de domínio hídrico \\
\hline & & - ha $(\%)$ & - \\
\hline Lote 1 & 9,0 & 0,58 & 1,16 \\
\hline Lote 2 & 8,3 & - & - \\
\hline Lote 3 & 8,2 & $1,06(13 \%)$ & $2,3(28 \%)$ \\
\hline Lote 4 & 10,4 & $0,85(8 \%)$ & $3,7(36 \%)$ \\
\hline Lote 5 & 10,3 & $0,6(6 \%)$ & $3,9(38 \%)$ \\
\hline Lote 6 & 10,6 & $1,3(12 \%)$ & $2,9(27 \%)$ \\
\hline Lote 7 & 7,8 & - & - \\
\hline Lote 8 & 7,4 & - & 0,25 \\
\hline Lote 9 & 7,8 & 0,68 & 1,3 \\
\hline Lote 10 & 8,8 & $1,63(18 \%)$ & $2,3(26 \%)$ \\
\hline Lote 11 & 8,3 & - & - \\
\hline Lote 12 & 8,0 & - & 0,2 \\
\hline Lote 13 & 8,6 & $0,6(7 \%)$ & $2,3(27 \%)$ \\
\hline Lote 14 & 9,8 & $1,1(11 \%)$ & $3,1(32 \%)$ \\
\hline Lote 15 & 10,2 & - & 1,6 \\
\hline Lote 16 & 8,9 & - & $3,6(40 \%)$ \\
\hline Lote 17 & 9,3 & - & 1,5 \\
\hline Lote 18 & 9,4 & - & 0,85 \\
\hline Lote 19 & 11,4 & - & 0,82 \\
\hline Lote 20 & 1,4 & - & - \\
\hline Lote 21 & 42,1 & $16,1(38 \%)$ & $13,52(32 \%)$ \\
\hline Total & 216,0 & $24,5(11 \%)$ & $45,3(21 \%)$ \\
\hline
\end{tabular}




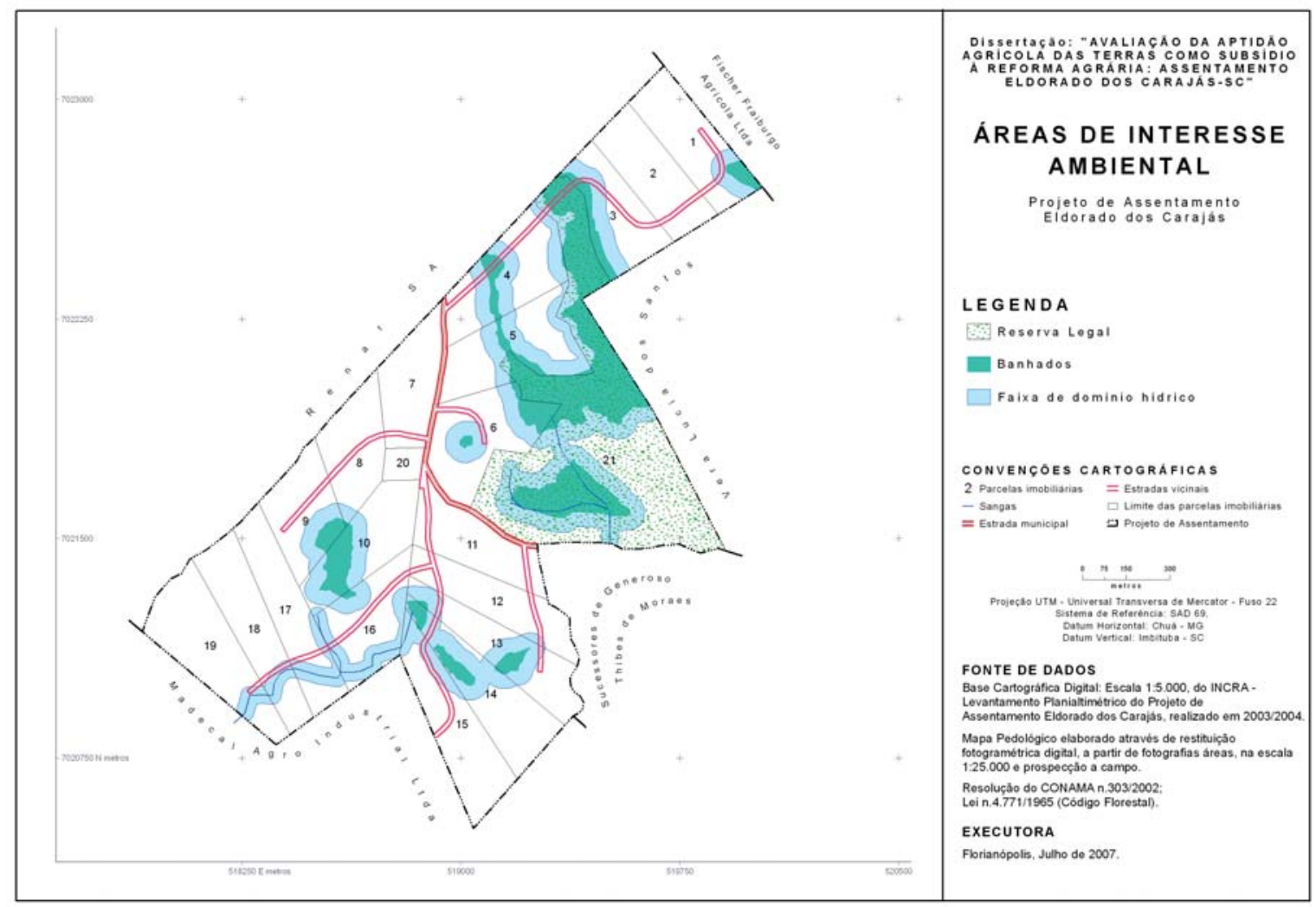

Figura 3. Mapa de áreas de interesse ambiental do PAEC.

A área de reserva legal, lote 21 , foi alocada na planta de parcelamento geral do assentamento em bloco na porção nordeste da área (Figura 3). A averbação da reserva legal, em propriedades rurais, atende a Lei Federal n. 4.771/65 - Código Florestal (Brasil, 1965), que exige, a título de reserva legal, uma área equivalente a $20 \%$ de sua área total na região Sul do Brasil. No caso da posse rural, a reserva legal é assegurada pelo Termo de Ajuste de Conduta. Nessas áreas, a vegetação não pode ser suprimida, podendo apenas ser utilizada sob regime de manejo florestal sustentável (Brasil, 1965).

No lote 21 , dos 42 ha da área de reserva legal averbados, cerca de $70 \%$ são formados por áreas de preservação permanente de banhado (38 \%) e faixa de domínio hídrico (32\%), destacado em negrito no quadro 6. O Código Florestal (Brasil, 1965), a partir de 2001, passou a admitir, para a pequena propriedade ou posse rural familiar, o cômputo de áreas de preservação permanente no cálculo do percentual de área de reserva legal. Entretanto, a norma determina que o regime de uso da área de preservação permanente não se altera quando passa a compor a área de reserva legal. Assim, dos 42 ha de área de reserva legal, somente 12,5 ha podem ser explorados sob regime de manejo florestal sustentável pelos agricultores.
Após o estudo da aptidão agrícola, as terras foram enquadradas em três grupos (3, 4 e 6$)$ e três classes (regular, restrita e inapta) de aptidão agrícola.

O resultado da avaliação da aptidão agrícola das terras (Quadro 7) mostra que aproximadamente $60 \%$ delas pertencem ao grupo 3, subgrupo 3(b), classe de aptidão agrícola restrita para lavouras. A classe $4 p$ de aptidão regular para pastagem plantada e a classe 6 sem aptidão para uso agrícola cobrem cerca de $40 \%$ das terras do assentamento e agrupam solos de baixa ou sem aptidão agrícola.

A classe 3(b) é a classe de maior potencialidade de uso agrícola do assentamento e predomina em aproximadamente $48 \%$ dos lotes - destacado em negrito no quadro 7. Sua distribuição é uniforme na área do PAEC, como mostra em laranja a figura 4.

O fator disponibilidade de nutrientes dos solos foi determinante para classificar as terras no subgrupo 3(b) de aptidão agrícola. Essas áreas apresentam solos que exigem elevadas doses de fertilizantes e corretivos, em função da baixa disponibilidade de nutrientes e dos elevados teores de matéria orgânica e alumínio trocável. Esse fator, no método, varia em função da inversão de capital. Por exemplo, deficiências de fertilidade e acidez do solo são limitantes nos níveis de manejo B com baixo investimento de capital. 
Quadro 7. Classes de aptidão agrícola e respectivas áreas por parcela imobiliária

\begin{tabular}{|c|c|c|c|c|}
\hline \multirow{2}{*}{ Parcelas imobiliárias } & \multirow{2}{*}{ Área } & \multicolumn{3}{|c|}{ Classes de aptidão agrícola das terras } \\
\hline & & $3(\mathbf{b})$ & $4 p$ & 6 \\
\hline Total & $216,0(100 \%)$ & $127,5(59 \%)$ & $61,9(28,7 \%)$ & $26,6(12,3 \%)$ \\
\hline
\end{tabular}

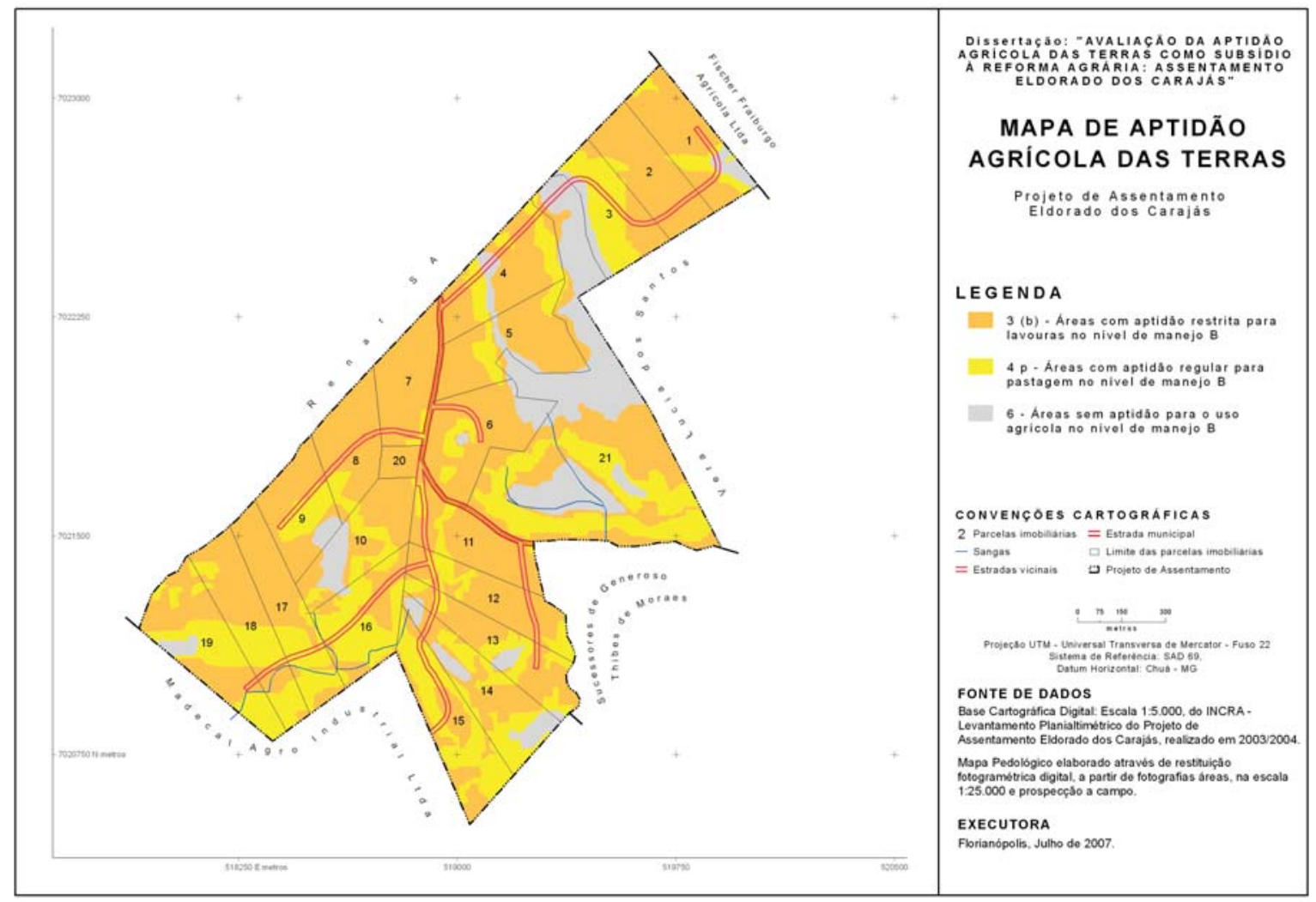

Figura 4. Mapa de aptidão agrícola das terras do PAEC.

As práticas de melhoramento compatíveis com nível de manejo $\mathrm{B}$ - empregadas no assentamento para o fator disponibilidade de nutrientes, principal fator limitante, excesso de água ou deficiência de oxigênio e impedimentos à mecanização - não foram viáveis para elevar as áreas a uma classe de aptidão agrícola de uso mais intensivo.

A figura 4 mostra, em amarelo no mapa, a distribuição da classe $4 \mathrm{p}$ em todos os lotes do assentamento, exceto no lote 20 , que constitui área comunitária. Essa classe predomina nos lotes 3, 15 e 16 - destacado em negrito no quadro 8.

A baixa aptidão agrícola das terras da classe $4 \mathrm{p}$ condiciona o uso das terras a atividades menos intensivas no nível de manejo B. Classes de declividade acima de $20 \%$, associada à baixa fertilidade dos solos, à pedregosidade e a afloramentos rochosos, constituem as principais limitações quanto ao uso agrícola dessas áreas.

De modo geral, as características limitantes da área estudada revelam que a sustentabilidade socioeconômica e ambiental depende, entre outros aspectos, de uma forte atuação da assistência técnica, por meio de alternativas econômicas de uso que associem técnicas de produção menos intensivas com práticas simples de conservação dos recursos naturais, como: adubações minerais ou orgânicas equilibradas e adoção de adubação verde, formação de cobertura morta, rotação e sucessão de culturas, cultivo em nível, renques de vegetação e terraços, entre outras.

A classe 6 sem aptidão para uso agrícola (representada em cinza na figura 4) ocorre em $12 \%$ da área. No lote 21 ela ocorre em cerca de $40 \%$ das terras (Quadro 8, em negrito). Nesta classe, as áreas 
apresentam grau forte de deficiência de oxigênio para o desenvolvimento radicular das plantas e grau muito forte de impedimento à mecanização provocada pela presença do lençol freático a pouca profundidade - em algumas situações, a $60 \mathrm{~cm}$ da superfície. De forma menos expressiva, as áreas apresentam limitação por declividade (classe de declive $>45 \%$ ) e baixa fertilidade natural dos solos.

O mapa de Conflito de Uso das Terras resultou da sobreposição do mapa de Aptidão Agrícola com os mapas de Uso e Cobertura das Terras e de Áreas de Interesse
Ambiental. A sobreposição gerou quatro classes de conflito de uso das terras: uso satisfatório-adequado; uso sobreutilizado, uso subutilizado e conflito ambiental.

A classe de uso satisfatório-adequado (Quadro 9 e, em verde, na Figura 5) ocorre em praticamente toda a área do assentamento, representando 44 \% da área total. Essa classe enquadra como uso mais intensivo das terras o cultivo restrito de lavouras ou pastagem ou indica áreas sem aptidão para uso agrícola. Nessas áreas, o uso atual corresponde ao uso indicado pela classe de aptidão.

\section{Quadro 8. Classes de aptidão agrícola e respectivas áreas por parcela imobiliária}

\begin{tabular}{|c|c|c|c|c|}
\hline \multirow{2}{*}{ Parcelas imobiliárias } & \multirow{2}{*}{ Área } & \multicolumn{3}{|c|}{ Classes de aptidão agrícola das terras } \\
\hline & & 3(b) & $4 p$ & 6 \\
\hline & & -1 & 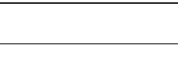 & 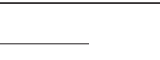 \\
\hline Lote 1 & 9,0 & $6,6(73 \%)$ & 1,5 & 0,9 \\
\hline Lote 2 & 8,3 & $8,0(96 \%)$ & 0,3 & - \\
\hline Lote 4 & 10,4 & $6,9(66 \%)$ & 2,7 & 0,8 \\
\hline Lote 5 & 10,3 & $8,2(79 \%)$ & 1,5 & 0,6 \\
\hline Lote 6 & 10,6 & $8,2(77 \%)$ & 1,2 & 1,2 \\
\hline Lote 7 & 7,8 & $7,4(95 \%)$ & 0,4 & - \\
\hline Lote 8 & 7,4 & $6,7(90 \%)$ & 0,7 & - \\
\hline Lote 9 & 7,8 & $5,2(67 \%)$ & 2,0 & 0,6 \\
\hline Lote 10 & 8,8 & $5,4(61 \%)$ & 1,8 & 1,6 \\
\hline Lote 11 & 8,3 & $7,2(87 \%)$ & 1,1 & - \\
\hline Lote 12 & 8,0 & $6,0(75 \%)$ & 2,0 & - \\
\hline Lote 13 & 8,6 & $5,3(62 \%)$ & 2,7 & 0,6 \\
\hline Lote 14 & 9,8 & $3,9(40 \%)$ & 3,8 & 2,1 \\
\hline Lote 17 & 9,3 & $6,0(64 \%)$ & 3,3 & - \\
\hline Lote 18 & 9,4 & $5,7(61 \%)$ & 3,7 & - \\
\hline Lote 19 & 11,4 & $5,8(51 \%)$ & 5,0 & 0,6 \\
\hline Lote 20 & 1,4 & $1,4(100 \%)$ & - & - \\
\hline Lote 3 & 8,2 & 2,2 & $5,0(61 \%)$ & 1,0 \\
\hline Lote 15 & 10,2 & 4,0 & $6,2(61 \%)$ & - \\
\hline Lote 16 & 8,9 & 3,3 & $5,6(63 \%)$ & - \\
\hline Lote 21 & 42,1 & 14,10 & 11,4 & $16,6(39 \%)$ \\
\hline Total & 216,0 & 127,5 & 61,9 & 26,6 \\
\hline
\end{tabular}

\section{Quadro 9. Distribuição das classes absoluta e relativa de conflito de uso das terras}

\begin{tabular}{|c|c|c|c|}
\hline \multirow[t]{2}{*}{ Classes } & \multirow[t]{2}{*}{ Descrição } & \multicolumn{2}{|c|}{ Área } \\
\hline & & ha & $\%$ \\
\hline Satisfatório - adequado & Áreas em que o uso atual atende à classe de aptidão agrícola definida. & 95,81 & 44,3 \\
\hline Sobre - utilizado & $\begin{array}{l}\text { Áreas em que o uso atual é mais intensivo que o recomendado pela classe de } \\
\text { aptidão agrícola. }\end{array}$ & 11,05 & 5,1 \\
\hline Subutilizado & $\begin{array}{l}\text { Áreas em que o uso atual é menos intensivo que o recomendado pela classe } \\
\text { de aptidão agrícola. }\end{array}$ & 46,65 & 21,5 \\
\hline Conflito ambiental & Compreende áreas em que o uso fere as leis ambientais. & 54,5 & 25,2 \\
\hline- & Estradas. & 8,39 & 3,9 \\
\hline- & Área total do assentamento. & 216,0 & 100 \\
\hline
\end{tabular}




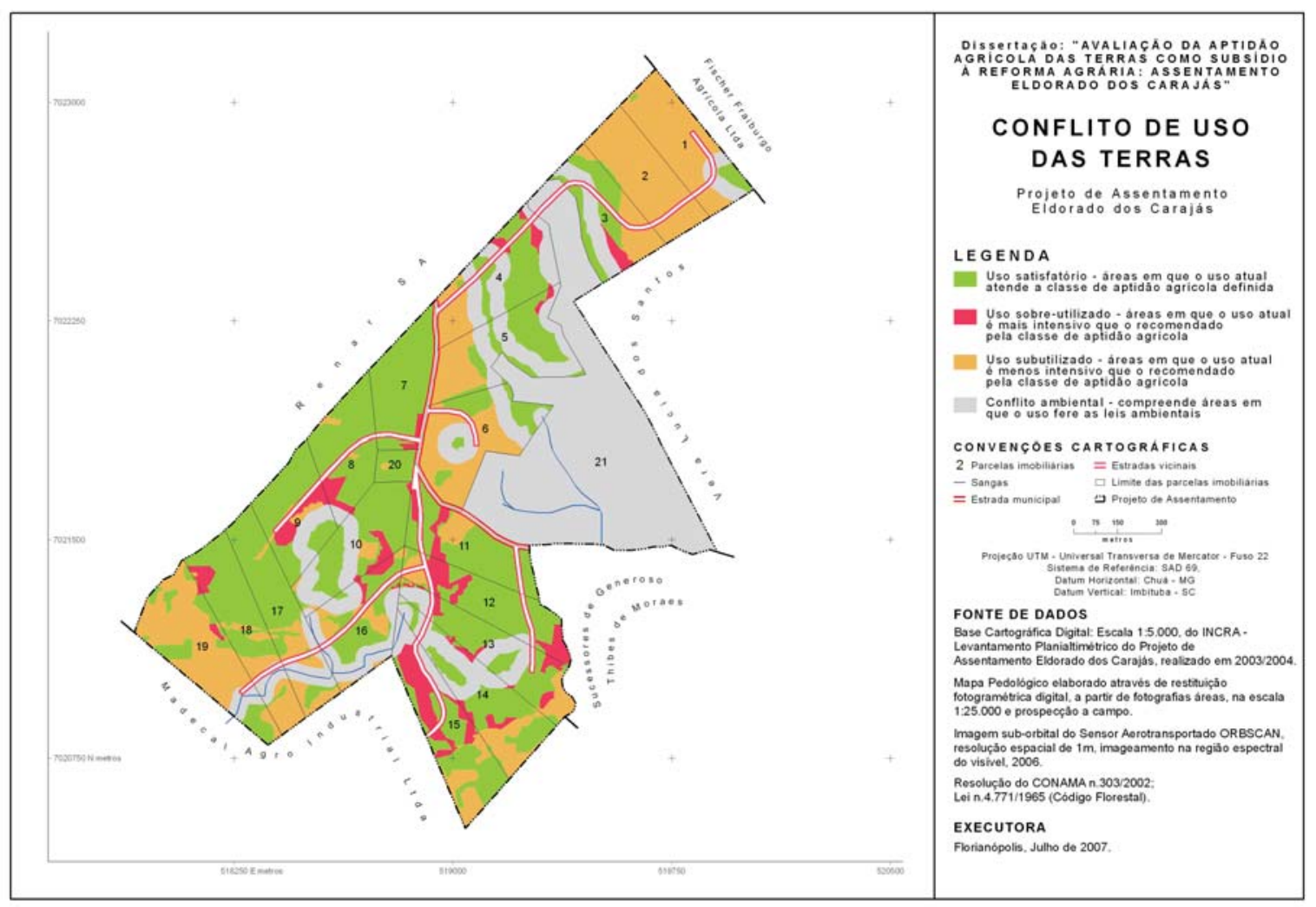

Figura 5. Mapa de conflito de uso das terras do PAEC.

As terras subutilizadas (representadas em amarelo na Figura 5) somam 21,5\% da área total do assentamento (Quadro 9). Nessas áreas, a classe de aptidão agrícola indicada é cultivo agrícola, porém as áreas atualmente estão ocupadas com pastagens ou exploração de espécies florestais. Nas áreas em que a classe de aptidão recomenda o uso com pastagens, os agricultores praticam a silvicultura.

Embora a classe de conflito de uso, conforme método utilizado, classifique essas áreas como subutilizadas, o uso atual com pastagem e, ou, reflorestamento pode caracterizar uso satisfatório-adequado, visto que a classe de aptidão agrícola considera a área restrita 3(b) para lavoura como tipo de uso mais intensivo da área. Fica a critério dos planejadores (agricultores) optar por um tipo de uso menos intensivo, que demande menos insumos, observadas as condições do manejo considerado, favorecendo a sustentabilidade econômica da área em consonância com a preservação dos recursos naturais. A mesma interpretação é dada para as áreas de pousio que resultam da sobreposição como área subutilizada; no entanto, o pousio é uma técnica de manejo do solo empregada pela agricultura itinerante e prática frequente no assentamento.

Conforme apresentado no quadro 9 e em vermelho no mapa da figura 5 , apenas $5 \%$ da área do assentamento está sendo utilizada mais intensivamente que o recomendado pela aptidão agrícola da área. A principal causa de conflito de uso é a presença de cultivos agrícolas e, ou, solo exposto em áreas com aptidão para pastagem ou outro uso menos intensivo.

Na classe de conflito ambiental (em cinza no mapa da Figura 5) a transformação das áreas de preservação permanente em áreas agrícolas ou a não recomposição da vegetação original nestas áreas resultam em conflito ambiental de cerca de $25 \%$ da área do assentamento (Quadro 9). A rotina de sobreposição do mapa de aptidão agrícola com o mapa de áreas de preservação permanente, antes de ser usada no planejamento de uma região, é recomendada por Pedron et al. (2006), pois o sistema proposto por Ramalho Filho \& Beek (1995) não considera a legislação ambiental na avaliação da aptidão agrícola das terras.

O interesse ambiental de determinadas áreas no planejamento territorial ultrapassa e independe da adequação às suas aptidões agrícolas, pois atendem à legislação ambiental que impõe algum tipo de limitação, que pode ser mais ou menos restritivo quanto à exploração da vegetação, segundo o instituto jurídico que a define, seja ele: área de preservação permanente ou reserva legal. 
Para o cumprimento do Termo de Ajuste de Conduta (TAC) de 17 de outubro de 2003 celebrado entre o Ministério do Meio Ambiente (MMA), o Ministério do Desenvolvimento Agrário (MDA), o INCRA, o Instituto Brasileiro do Meio Ambiente e dos Recursos Naturais Renováveis (IBAMA) e o Ministério Público Federal (MPF) visando à regularização do licenciamento ambiental dos projetos de assentamentos do PNRA, as áreas de conflito ambiental serão obrigatoriamente objeto de estudos pelos tomadores de decisão diante da necessidade de preservação e conservação dos recursos naturais e da fixação das famílias recém-assentadas nas áreas rurais.

\section{CONCLUSÕES}

1. No tocante ao uso e cobertura das terras, verificou-se que em praticamente toda a área do assentamento é praticada alguma atividade agrícola, seja com cultivos agrícolas, pastagens ou exploração florestal. Atividades de uso mais intensivo do solo, como os cultivos anuais, predominam na área.

2. Com relação às áreas de interesse ambiental, aproximadamente $52 \%$ da área do assentamento apresenta alguma restrição legal. A adequação legal das áreas de preservação permanente nos lotes levaria a uma redução significativa das áreas de produção agrícola, pois a única área de interesse ambiental alocada na planta geral de parcelamento do assentamento foi a de reserva legal.

3. Quanto às classes de solos, verificou-se que o NVdf cobre $76 \%$ das terras do PAEC, predominando em relevo ondulado e forte ondulado. A baixa disponibilidade de nutrientes e a toxidez por alumínio representam suas principais limitações quanto ao uso agrícola. A unidade RLd cobre $12,5 \%$ das terras com forte grau de limitação decorrente da pequena espessura do perfil associada ao predomínio de relevo forte ondulado. A unidade GMa cobre 11\% das terras, e as suas maiores limitações referem-se a condição periódica ou permanentemente saturada por água e baixas reservas de nutrientes e toxidez por $\mathrm{Al}$.

4. A avaliação de aptidão agrícola das terras do PAEC resultou em três classes de aptidão, no nível de manejo B. O grupo 3, classe 3(b), de maior potencial agrícola, abrange $59 \%$ das terras, cerca de $29 \%$ pertencem à classe $4 p$ e $12 \%$ à classe 6 . Essa análise subsidia a intervenção da assistência técnica na implementação de estratégias de melhoramento produtivo dos estabelecimentos familiares, sobretudo daqueles que reproduzem o pacote tecnológico da agricultura tradicional por meio do trabalho familiar.

5. A não alocação das áreas de preservação permanente na planta geral de parcelamento do PAEC originou a classe de conflito de uso das terras mais expressiva na área, ou seja, em aproximadamente $25 \%$ da área do assentamento ocorre conflito de uso ambiental.

6. O uso do SIG para a sobreposição dos mapas temáticos permitiu a análise espacial e individual dos lotes quanto à aptidão agrícola e suas principais limitações no nível de manejo B e a espacialização do uso atual e os conflitos de uso das terras por parcela imobiliária com significativa redução de tempo e subjetividade nos cruzamentos, quando comparado com o método manual.

\section{LITERATURA CITADA}

BACIC, I.L.Z. Development of a land evaluation method for the southern agro-ecological zone of Santa Catarina State - Brazil. LOCAL, International Institute for Aerospace Survey and Earth Sciences, 1998. 159p. (Tese de Mestrado)

BRASIL. Lei $\mathrm{n}^{\circ}$ 4.771, de 15 de setembro de 1965. Institui o Novo Código Florestal. Disponível em: <http:// www.presidencia.gov.br/legislação>. Acesso em: 15 jun. 2006.

CALDERANO FILHO, B.; SANTOS, H.G.; RAMALHO FILHO, A.; ClAESSEN, M.E.C.; CARVALHO JUNIOR, W.; CHAGAS, C.S.; CALDERANO, S.B.; LUZ, L.D.; MOTCHI, E.P. \& WITTERN, K.P. Avaliação da aptidão agrícola das terras da microbacia do Córrego da Tábua, no município de São Fidélis, RJ. Rio de Janeiro, Embrapa Solos, 2004. 43p. (Embrapa Solos. Boletim de Pesquisa e Desenvolvimento, 47)

CONAMA $\mathrm{n}^{0} 303$, de 20 de março de 2002. Dispõe sobre parâmetros, definições e limites de Áreas de Preservação Permanente. Disponível em: <http://www.mma.gov.br>. Acesso em: 15 jun. 2006.

CARDOSO, E.L.; SPERA, S.T.; PELLEGRIN, L.A. \& SPERA, M.R.N. Solos do assentamento Tamarineiro I Corumbá,-MS: Caracterização, limitações e aptidão agrícola. Corumbá, Embrapa Pantanal, 2002. 26p.

CHAGAS, C.S.; CARVALHO JUNIOR, W.; PEREIRA, N.R. \& FERNANDES FILHO, E.I. Aplicação de um sistema automatizado (ALES - Automated Land Evaluation System) na avaliação das terras das microrregiões de Chapecó e Xanxerê, Oeste catarinense, para o cultivo de grãos. R. Bras. Ci. Solo, 30:509-522, 2006.

EMPRESA BRASILEIRA DE PESQUISA AGROPECUÁRIA EMBRAPA. Centro Nacional de Pesquisa de Solos. Levantamento de reconhecimento dos solos do Estado de Santa Catarina. Rio de Janeiro, Embrapa Solos, 1998. 1 mapa. Escala 1:250.000.

EMPRESA BRASILEIRA DE PESQUISA AGROPECUÁRIA EMBRAPA. Centro Nacional de Pesquisa de Solos. Sistema brasileiro de classificação de solos. 2.ed. Rio de Janeiro, Embrapa Solos, 2006. 306p.

FERNANDES, M.F.; BARBOSA, M.P. \& SILVA, M.J. O uso de um sistema de informações geográficas na determinação da aptidão agrícola das terras de parte do setor leste da bacia do Rio Seridó, PB. R. Bras. Eng.Agríc. Amb., 2:195198, 1998 
FORMAGGIO, A.R.; ALVES, D.A. \& EPIPHANIO, J.C.N Sistemas de informações geográficas na obtenção de mapas de aptidão agrícola e de taxa de adequação de uso das terras. R. Bras. Ci. Solo, 16:249-256, 1992.

GUANZIROLI, C.; ROMEIRO, A.; BUAINAIN, A.M.; Di SABBATO, A. \& BITTENCOURT, G. Agricultura familiar e reforma agrária no século XXI. Rio de Janeiro, Garamond, 2001. 288p.

HAMADA, E.; LOPES ASSAD, M.L. \& PEREIRA, D.A. Aptidão agrícola na área de recarga do Aquífero Guarani: Caso da microbacia hidrográfica do Córrego do Espraiado, Ribeirão Preto, SP. Eng. Amb., 3:62-071, 2006.

INSTITUTO NACIONAL DE COLONIZAÇÃO E REFORMA AGRÁRIA - INCRA. Projeto Básico Ambiental: Projeto de Assentamento Eldorado dos Carajás. Curitiba, 2006. 320 p.

LOPES ASSAD, M.L.; HAMADA, E. \& CAVALIERI, A. Sistema de informações geográficas na avaliação de terras para agricultura. In: ASSAD, M.L.L. \& SANO, E.E. Sistema de informações geográficas: Aplicações na agricultura. Brasília, Embrapa-CPAC, 1998. p.191-232.

RAMALHO FILHO, A. \& BEEK, K.J. Sistema de avaliação da aptidão agrícola das terras. 3.ed. Rio de Janeiro, Embrapa/ CNPS, 1995. 65p.

RAMOS, D.P.; ASSIS, D.S.; MENDONÇA-SANTOS, M.L.; MANZATTO, C.V. \& COSTA, J.R.F. O assentamento como indutor do desenvolvimento agrícola sustentável: Um novo modelo de reforma agrária para o país. Rio de Janeiro, Embrapa Solos, 2001. 23p.
PEDRON, F.A.; POELKING, E.L.; DALMOLIN, R.S.D.; AZEVEDO, A.C. \& KLAMT, E. A aptidão de uso da terra como base para o planejamento da utilização dos recursos naturais do município de São José do Polêsine - RS. Ci. Rural, 36:105-112, 2006.

SANTOS, F.J. \& KLAMT, E. Gestão agroecológica de microbacias hidrográficas através de técnicas de geoprocessamento e sensoriamento remoto - caso Fazenda Pantanoso. Ci. Rural, 34:1785-1792, 2004.

SILVA, C.E.M. Análise agroambiental de imóveis para uma reforma agrária sustentável. NÚCLEO DE ESTUDOS AGRÁRIOS E DESENVOLVIMENTO RURAL MINISTÉRIO DO DESENVOLVIMENTO AGRÁRIO NEAD/MDA. 2006. Disponível em: <http:// www.nead.org.br>. Acesso em? 7 fev. 2006.

SILVA, E.B. Avaliação da aptidão agrícola das terras como subsídio à reforma agrária: Assentamento Eldorado dos Carajás. Florianópolis, Universidade Federal de Santa Catarina, 2007. 147p. (Tese de Mestrado)

VASCONCELOS GOMES, J.B.; LUMBRERAS, J.F.; OLIVEIRA, R.P.; BHERING, S.B.; ZARONI, M.J.; ANDRADE, A.G. \& CALDERANO, S.B. Aptidão para reflorestamento das Sub-bacias dos Canais do Mangue e do Cunha, município do Rio de Janeiro. R. Bras. Ci. Solo, 29:459-466, 2005.

WOLSTEIN, A.R.P.; LIMA, E.M.; AMARAL, E.F.; BRAZ, E.M.; PINHEIRO, F.L.N.; FRANKE, I.L.; SANTOS, M.H. \& SILVA, R.F. Metodologia para o planejamento, implantação e monitoramento de projetos de assentamentos sustentáveis na Amazônia. Rio Branco, Embrapa-CPAF/AC/INCRA/Funtac, 1998. 29p. 